\title{
Environmental Crisis, Cli-fi, and the Fate of Humankind in Richard Jefferies' After London and Robert Harris' The Second Sleep
}

\section{Adrian Tait}

Correspondence: adrian.tait@outlook.com

Peer review: This article has been subject to a double-blind peer review process

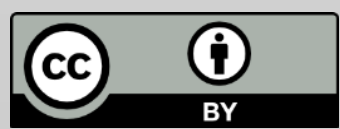

Copyright notice: This article is issued under the terms of the Creative Commons Attribution License, which permits use and redistribution of the work provided that the original author and source are credited.

You must give appropriate credit (author attribution), provide a link to the license, and indicate if changes were made. You may do so in any reasonable manner, but not in any way that suggests the licensor endorses you or your use. You may not apply legal terms or technological measures that legally restrict others from doing anything the license permits.

https://creativecommons .org/licenses/by/4.0/

\begin{abstract}
This article discusses two instances of 'Anthropocene fiction' (Trexler, 2015: 4) that engage with the environmental crisis that industrial modernity has generated: Richard Jefferies' After London (1885), and Robert Harris' The Second Sleep (2019), which both depict a future in which technological civilisation has collapsed, and the non-human world is resurgent. Like climate change fiction, or cli-fi, these novels are concerned with the elusive and unpredictable environmental risks that modern societies inadvertently create, and with finding ways to negotiate the representational challenge of those risks; unlike many instances of climate change fiction, however, these novels do not set out to warn their readers of what is to come, or lament the disaster they depict. They are instead concerned with the legacy of technological civilisation - a legacy of risk and uncertainty - and the question of whether that legacy can ever be escaped. Neither novel offers an answer; but nor do they foreclose its possibility.
\end{abstract}

Keywords: modernity; cli-fi; risk; uncertainty; apocalypse; non-human 


\section{Introduction}

My aim in this article is to explore two narratives that depict the apocalyptic aftermath of society's breakdown, and discuss their relationship to and bearing on contemporary climate change fiction, or 'cli fi' (Johns-Putra, 2016: 267). In Richard Jefferies' After London; or Wild England, first published in 1885, an unspecified 'event' (Jefferies, 2017: 15) has precipitated the collapse of modern, industrialized society. Robert Harris' The Second Sleep, published in 2019, also depicts a mediaevalesque future; it too takes as its point of departure some form of catastrophe or upheaval that has transformed society but whose nature is surrounded in mystery.

What bearing might these two novels have on discussions about the nature and role of climate change fiction, which is, by contrast, explicitly concerned 'with anthropogenic climate change or global warming as we now understand it' (Johns-Putra, 2016: 267)? Climate change fiction has become increasingly popular over the last decade, but whilst cli-fi has been 'identified as a genre of fiction in its own right' (Johns-Putra, 2016: 267), Andrew Milner and J. R. Burgmann have argued that it is more accurately regarded as 'a subgenre of sf' (2018: 1). As they contend, 'both climate fiction's texts and its practitioners articulate a structure of feeling that accords centrality to science and technology, in this case, normally climate science' (Milner \& Burgmann, 2018: 5). It is on the basis of that climate science that, as Adam Trexler argues in 'the first book-length study of climate change fiction' (Johns-Putra, 2016: 272), its practitioners set out 'to explain, predict, implore, and lament' (Trexler, 2015: 9). The related point, argue Milner and Burgmann, is that, 'understood as sf', cli-fi has a 'pre-history', a pre-history that encompasses 'a flood narrative', such as Jefferies' After London (2018: 5-7). Consequently, and although 'not strictly speaking a climate fiction' (Ibid: 7), Jefferies' novel can be seen as a part of a longer sf tradition that also encompasses cli-fi.

Whilst Milner and Burgmann set the precedent for including Jefferies' novel in a 'pre-history' of cli-fi, there is, however, a more compelling reason for linking it to a discussion of climate fiction. As I argue in this article, Jefferies' novel responds to the deeper crisis created by industrial modernity, a crisis that is itself long-standing, and of which climate change is just one expression; for decades and perhaps even centuries, the planet's ability to sustain human existence has been strained by a whole range of human impacts, from ocean acidification to chemical pollution. As Jefferies' novel highlights, modern societies are imperilled by hazards of their own technological making. Consequently, it might be argued that After London is a form of sf that 'accords centrality to science and technology' (Ibid: 5) only to underline the risks of doing so. 
No less importantly, Jefferies' genre-defying novel also responds to the representational challenge of this 'crisis of "modernism" (Hooker, 1996: 43), and to the 'peculiar forms of resistance' that it presents to modern, realist fiction (Ghosh, 2016: 9). As Amitav Ghosh has argued, it is not simply that, with its exclusive focus on human narratives, realist fiction is poorly equipped to engage with risks that defy the human sense of scale in space and time; in what he terms 'the time of the Great Derangement' (Ibid: 11), realist fiction is also complicit with the Western reluctance to acknowledge the depth and extent of a crisis that, although of its own making, defies its comfortable, bourgeois sense of what is likely or probable $(16-17,25)$. Thus, and as Ghosh insists, 'the climate crisis is also a crisis of culture, and thus of the imagination' (Ibid: 9), and one possible representational response lies in exactly those hybrid forms of fiction that realism has 'banished' (Ibid: 66).

The continuing relevance of Jefferies' work is suggested by a much more recent novel, Robert Harris' The Second Sleep. First published in 2019, Harris' "genre-bending thriller" (Clark, 2019) also shares a number of thematic resemblances with Jefferies' novel, such as the latter's concern with the fragility of technological civilization, the multiple risks that civilization generates, and its legacy of uncertainty; it too leaves the cause of that apocalypse opaque, underlining the extent to which its future world is also entrapped by a lack of understanding. Although the two novels were published over a century apart, both present a fictive future haunted by the condition of not-knowing, of not being able to know, or of being denied knowledge. More or less unwittingly, these future societies are condemned to repeat the same mistakes as those they succeeded.

As this brief outline suggests, both novels are recognisable instances of Trexler's 'Anthropocene fiction', responding to a 'human process' of geophysical transformation that was already underway in the Victorian period' (Trexler, 2015: 4). Since neither is, however, directly concerned 'with anthropogenic climate change ... as we now understand it' (JohnsPutra, 2016: 267), they also avoid some of the pitfalls inherent in the kinds of climate change fiction that Trexler surveyed: neither implores or laments (Trexler, 2015: 9); neither defers the risks that modernity generates, or reduces them to a 'single tsunami' (25); and whilst both imply that modernity's downfall is a dialectic inevitability, neither extrapolates from this the kind of extreme, end-of-the world scenario that climate fictions often offer (see also Garrard, et al., 2019: 39, 120). Rather, these narratives are concerned with the kind of society that might reconstruct itself in modernity's shadow, 'after London ended' (Jefferies, 2017: 3), and whether that shadow can ever be escaped. 
My intention in this article is, therefore, to evaluate these novels as part of a wider, interlinked response to the nature and impact of modernity, a response that also encompasses cli-fi itself. The article has three main sections. The first establishes the link between modernity, risk, and uncertainty, with which the climate change debate is (still) caught up (Garrard et al., 2019). The second turns to the novels themselves, and explores their themes of risk and uncertainty. The third shifts the focus to the representational decisions each makes - to their narrative strategies and the kinds of generic fluidity that result. As I conclude, these novels are relevant to our understanding of 'the complexity of climate change as a cultural phenomenon' (Johns-Putra, 2016: 267) because they respond to the same modernizing impulse with which climate change is caught up, and to the uncertainties and potentially cataclysmic risks that impulse generates, and because, like cli-fi, they too engage with the representational challenge of an environmental crisis that is complex, mutable, and elusive. No less significantly for our understanding of how fiction (such as cli-fi) might respond to environmental crisis, both novels refuse 'to foreclose the possibility of an optimistic outcome' (Frost, 2017: xlvi); whilst neither identifies what that outcome might be, their emphasis on the renewed dynamism and agentiality of the non-human world - a world that cannot now be dismissed as inert, passive, or pliable tentatively implies that any future hinges on the question of how that world is taken into account.

\section{Modernity, Risk, Uncertainty}

As Ulrich Beck has argued, modern societies are by their very nature risk societies (1992: 19-23), and the risks they inadvertently create mark the limit of scientific understanding: often, those risks take the form of what Timothy Morton calls 'hyperobjects', 'massively distributed in time and space relative to humans' (2013: 1), making it all the more difficult to understand, adapt to, or mitigate them. But whilst modernity has generated unforeseen and unpredictable risks, it has also created less resilient, more vulnerable societies, heavily dependent on technology, but insulated from any sense of their own vulnerability by a false sense that the non-human world has itself been mastered; as Ghosh points out, the 'distinctive mark of [this] "modern" worldview' (2016: 22) is that gradualism has replaced catastrophism (Ibid: 17-20), 'banishing [...] the improbable' (Ibid: 17), and substituting a view of 'Nature [as] moderate and orderly' (Ibid: 22). In other words, risk societies are also societies that, paradoxically, believe in a world that is comprehensible, predictable, and pliable; when the evidence offers an incontrovertible challenge to that paradigm, there is a tendency to disbelieve it. Thus, and whilst uncertainty may be used as a reason to exercise caution (Garrard et al., 2019: 233), late modern societies tend instead towards intransigent inertia. In spite of 
their inherent fragility, these societies live as though the 'scientific consensus [...] were not true' (MacDuffie, 2018: 543), or actively exploit uncertainty to justify inaction (Garrard et al., 2019: 233): in the literature of climate change denial, for example, 'the limitations of climate models' projections are a constant - and not unjustified - refrain' (Garrard et al., 2019: 6). Consequently, questions of certainty and uncertainty, 'truth and falsity' (Trexler, 2015: 4) continue to overshadow debates about climate change. Indeed, it is precisely to avoid the 'extraordinarily heightened rhetoric' generated by those debates that Trexler refers to 'Anthropocene fictions' rather than cli-fi (Trexler, 2015: 4).

As this brief discussion highlights, modern societies are caught in a complex bind. On the one hand, modernity assumes a model of the nonhuman world as passive and predictable, yet it is neither, as the impacts of climate change already demonstrate: '[e]xtreme climate change,' note Milner and Burgmann, 'necessarily involves everyday improbabilities: radically extreme weather events on the one hand, and a nonhuman Nature that is both sentient and proactive on the other' (2018: 1). On the other, modernity has created more fragile and less resilient societies, whilst exposing them to an array of risks whose multiple, unforeseen consequences are now 'a dominant force in history and society' (Beck, 1992: 22): the uncertainty surrounding those risks has itself become a major factor in societies' growing vulnerability. How, then, do After London and The Second Sleep respond to the 'self-endangering, "civilized" world' that modernity has generated (Beck, 1995: 13)?

\section{Themes of Risk and Uncertainty}

After London and The Second Sleep take as their premise the collapse of the modern world, a collapse which may not have been understood at the time, and whose nature is now impossible to unpick; this failure to understand what has happened is part of a wider loss of knowledge and understanding, which has in turn shaped the primitive worlds that the novels depict. In After London, for example, there is no agreement about what happened, or why, and even the existence of this uncertainty is a matter of mystery (Jefferies, 2017: 14), since only a few generations have (it is said) elapsed since the event (Ibid: 3 ): 'it may be that even when they were proceeding, the causes of the changes were not understand' (14). 'All that seems certain is, that when the event took place, the immense crowds collected in cities were most affected, and that the richer and upper classes made us of their money to escape' (Ibid: 15). Yet 'nothing has ever been heard' of the 'multitudes that left the country' (Ibid: 15). One explanation is that the multitudes did not leave, and they filled the cities only to die there, an alternative implied by stories of the 'ancient cities' whose sites - some now 'lost in the forest', others covered by swamp - 
are avoided because they cause 'ague or fever' (Ibid: 33). It may be that plague played some part in modernity's downfall; it may also be that society's collapse was precipitated by the accidental release of the 'strange and unknown chemicals collected by the wonderful people of those times' (Ibid: 166), chemicals that now form part of the toxic cloud that marks the site of London. Ultimately, 'nothing is certain and everything confused' (Ibid: 14), and that confusion reflects the fragility as well the vulnerability of an 'industrial-capitalist colossus' (Beck, 1995: 5) which was over-dependent on technologies that only a handful understood or could fix once broken (Jefferies, 2017: 15-17): when 'the cunning artificers of the cities all departed', 'everything fell quickly into barbarism' (Ibid: 17), and 'the secrets of their sciences' (16) were quickly lost.

The continuing fascination of Jefferies' premise is underlined by Harris' The Second Sleep, which takes as its own basis the 'systemic collapse of technical civilisation' (Harris, 2019: 57). In Harris' novel, as in Jefferies' (Jefferies, 2017: 17), there are theological explanations for that collapse, and they are particularly prominent in Harris' fictional future, where a resurgent church has assumed authority, and it is believed that 'God had punished the ancients for their elevation of science above all else' (Harris, 2019: 60). There is, moreover, a certain truth to the church's teaching: 'technical civilization' is indeed raised on the achievements of modern science, and it was those achievements - that very sophistication - that rendered 'it [technical civilization] uniquely vulnerable to total [and rapid] collapse' (Ibid: 58). Yet scientists were also those intent on warning society about its own inherent fragility (Ibid: 57-59). Led by a Nobel prize-winner named Morgenstern, the most chilling aspect of their warning is, however, its tacit acceptance that nothing by then (the year is given as 2022) could be done to save society from any one of several 'catastrophic scenarios that fundamentally threaten the existence of our advanced science-based way of life' (Ibid: 57). Whatever the trigger, and whether it is climate change, pandemic, or super-volcano, or any of the other possibilities that the scientists identify (Ibid: 57), the aim must be to find a way to restore 'technical civilisation' as quickly as possible (58).

In Harris' novel, therefore, society does not pull back from the brink; it simply cannot. Moreover, its collapse is of a kind so sudden and severe that knowledge of what is happening and why is quickly lost, if it was ever fully understood at the time. Whilst societies of like-minded antiquarians (Ibid: 55-56) - and sometimes, simply, the curious - struggle to piece together the truth, their efforts are humbled not only by the way that the knowledge of 'the ancients' disappeared, perplexingly, into 'The Cloud' (56), but by the way in which knowledge is itself now regarded. In Jefferies' future, the ruling elite has little if any interest in the ancients, or 'the 
secrets of their science' (Jefferies, 2017: 16), and the only exception is the young and idealistic misfit Sir Felix Aquila, who recognises the potential importance of that learning, and whose quest occupies the novel's second part (Ibid: 39). In Harris' narrative, by contrast, the church frowns upon and ultimately suppresses any interest in the ancients, whilst secretly finding ways in which to seek out and secure their knowledge (Harris, 2019: 218-219, 321).

As these novels underline, modernity has failed to address the threat of natural disaster, such as pandemic, but it has also succeeded in creating new and unexpected dangers, from atmospheric pollution and toxic spills, which in Jefferies' novel have created places where 'the earth was poison, the water poison, the air poison' (Jefferies, 2017: 166), to the still greater challenge of a warming climate, signalled early on in Harris' novel by the fact that in England's west country, the parakeet is now 'common' (Harris, 2019: 3). For these future societies, however, these conditions are simply a lived reality, the inexplicable legacy of a past none now understand (or admit to understanding). In turn, their own futures are shaped by this lack of understanding, forcing each to recapitulate its own now forgotten history. The opening part of Jefferies' novel is entitled the 'Relapse into Barbarianism' (Ibid: 3), whilst Harris' novel depicts a society in which wars are again being fought against old enemies (France, Scotland), and lives are once again lived in fear of a repressive church. It also seems as if the same mistakes may be made again. Although Morgensten has failed to resurrect the technological civilisation he said could not be saved, mill owners are already seeking out the kind of machinery will enable them to escape the 'brake' that 'Nature' places on their 'expansion' (Harris, 2019: 120). It may just be a question of time before they (re)discover steampower, and the Anthropocene is once again underway (Watts' invention of the steam engine in 1784 is often given as the Anthropocene's nominal ground zero) (Trexler, 2015: 1).

These future societies are, therefore, brought low by their own lack of understanding: as they try to negotiate the hazards left to them by modernity, uncertainty has itself become a form of risk. For the novelist, however, a premise such as this is at once a problem to be negotiated and an opportunity to be exploited. How do these novels respond to the representational challenge of the themes with which they engage?

\section{Representing Risk and Uncertainty}

For Anthropocene fictions that seek to respond, as these novels do, to the risks and uncertainties that modernity generates, the realist mode may itself be inadequate. Uncertainty can be rendered as mystery or a puzzle to be solved - like the question of what precipitated the collapse of technological civilisation in these novels - but realist fiction typically 
requires the satisfaction of a tidy resolution, and in these fictional worlds, answers are in short supply. Nor is realist fiction necessarily able to encompass the kinds of risk that modernity generates, hyperobjects that occupy a daunting temporal and spatial vastness (Ghosh, 2015: 62-63), since readers of realist fiction expect their stories to centre on human lives, operate over human time-scales, and focus on typically human concerns (such as love, relationships, or intergenerational strife).

These concerns have been variously highlighted by those who recognise the challenge that hyperobjects (like climate change) pose to the realist novel, such as Amitav Ghosh (2016) and Timothy Clark (2015). However, as Ghosh points out and Clark acknowledges, fiction need not conform to these realist rules. A more experimental (Ghosh, 2016: 11, 24) form of fiction might find ways of decentring the human - and of going beyond a human sense of scale - whilst also invoking uncertainty as an operative principle within the novel.

How do these novels negotiate the twofold difficulty of representing risk (when that risk takes the form of enduring ecological upheaval and societal transformation) and of representing uncertainty? Both employ the sf device of setting the action in the future: in Harris' novel, for example, over 800 years has elapsed since the apocalypse, which enables ecological transformation to run its course, whilst also explaining and legitimating this future world's uncertainty about its own past (it is only the crucial discovery of a letter from Morgenstern that makes any sense of what might have happened). By contrast, After London opens with a scholar's panoramic survey of technological civilisation's collapse, its swift erasure, and the emergence of warring states and peoples, all in a state of conflict and competition with each other and with a resurgent, non-human world. Combining human and non-human histories at various different scales, the scholar's chronicle enacts a decisive shift in focus away from the individual and towards the collective (Ghosh, 2015: 77). It also resists the temptation to lapse into an omniscient third-person narrative: although the unnamed scholar is palpably present in the account that he (or she) gives, it is only to draw attention to its gaps and limitations (for example, little is known of what might have happened to the world beyond the United Kingdom's shores).

In Jefferies' novel, it is, moreover, the gaps in the scholar's chronicle that sets up a quest-like narrative in the novel's second part, now related by a more conventional third-person narrator. The narrative quickly establishes Sir Felix's refusal to conform to the nobility's values, his contrary fascination with knowledge, and his need to find some way in which to prove himself. It also underlines some of the many hazards (both natural and manufactured) that Felix will have to negotiate if he is to succeed. The 
stage is set for a journey of discovery which will, the reader hopes, provide answers about the nature of 'the event', and enable Felix to demonstrate the kind of superior wisdom and understanding that will point to a better and less brutish future. Yet the second part of the novel confounds the expectations it creates. Felix's quest is never rewarded with any new understanding of 'the event', and no great discovery that might enable him to launch a new society. Instead, it becomes clear that, on the few occasions when Felix has been able to use his own superior understanding, his primary objective is to find ways in which to reinforce his own standing, and establish his own authority over both people and place: he is, in other words, re-enacting both the Victorian 'romance of empire' (Hooker, 1996: 49) and the Enlightenment fantasy of mastery and possession (Ibid: 4849). Furthermore, the narrative underlines both Felix's continued lack of knowledge - his journey is nearly cut short by his encounter with the toxic swamp that now marks the site of sunken London, an encounter which he is lucky to survive - and his powerlessness before an agential but indifferent non-human world. His quest ends, inconclusively, as he sets off on his return trip, leaving the reader none the wiser, unsettled and perhaps frustrated by a story that fails to supply any answers to the question it poses. Other endings, wrote Edward Thomas of the novel, 'could have been found to conform to the needs of perhaps a majority [of readers]. But to end with suspended breath is [...] in keeping with this age' (Thomas, 1909: 260) - the age we now recognise of the Anthropocene. That open ending is, in other words, a final, categorical marker of the uncertainties in which the novel deals, and it underlines how different it is to the realist novels that were then in the ascendency, with their progressivist, comforting visions, and neat resolutions.

By contrast with After London, Harris' novel takes a more conventional approach to its material, by situating a soluble, human-sized mystery within the larger, incomprehensible story of ecological upheaval and technological collapse. The novel's opening line establishes that this is the year 1468, and that this is England (Harris, 2019: 1), but the appearance of parakeets on the next page throws both facts into doubt. As the narrative follows the progress of its young protagonist, Fairfax, it becomes clear that this is a future world, which has reset its calendar in the wake of some kind of apparent apocalypse. At this point, however, the larger mystery is subsumed within a more local, parochial one, as Fairfax's curiosity draws him into the search for the underground complex or 'ark' (Ibid: 320) in which Morgenstern and his followers may have waited out the chaotic aftermath of the disaster. This too is a quest (Ibid: 319), but it ends very differently to Felix's: Fairfax locates the now empty ark, only to be caught by his superior, Bishop Pole. He too is curious to know 'the truth of this place', but only so he may then bury it, along with all the other 
secrets that the church keeps (Ibid: 321); in what the reader will recognise as the dramatic enactment of just desserts, Pole is buried alive moments later when the weakened bunker collapses.

Thus, Harris' novel also leaves key questions unanswered. Fairfax dies along with Pole, and whatever truths the ark might have contained lies buried with both. This burying of the truth is itself a metaphor for the wider uncertainties that the novel fails to resolve: although the (now empty) ark has been discovered, the fate of its inhabitants is simply guessed at, and there is no discovery of the truth about the apocalypse itself. As it becomes clear, Harris' novel responds to the indeterminacy of the modern condition not by seeking to resolve its uncertainties, but by embodying indeterminacy in its own, open-ended narrative structure. Even as Fairfax's story comes to an end, the story of which it forms a small, even inconsequential part continues, without solution or resolution.

Furthermore, and whilst Harris' novel lacks Jefferies' sustained, opening account of a resurgent nature, the narrative quietly insists on the agency of the non-human world. The novel opens with the solitary figure of Fairfax on horseback, slowed not only by 'his grumpy beast [...] more mule than horse' (Ibid: 4) but by a wet and inimical landscape that impedes his progress and emphasises his isolation and vulnerability in a much larger, non-human world (3-5): what was once near is now far-off (4). Human achievements, like humans themselves, are dwarfed by the non-human. As it becomes clear, the earth has both literally and metaphorically erased almost every trace of technological civilization, bar the occasional Lego brick, concrete tower, or Apple phone.

With their open endings and strong sense of humankind's littleness, what kinds of novel are these? Both novels are difficult to classify, except, perhaps, in the most general terms, as Anthropocene fictions. They avoid 'apocalypse, progress and pastoral' (Garforth, 2005: 397), 'three of the dominant tropes through which human social relationships with nature have been managed and imagined in modernity' (Ibid: 393-4), and their worlds, whilst self-evidently post-apocalyptic, have had time to reestablish the parameters of new forms of society, even if those societies are haunted by their pasts. These future societies come close to the dystopian, particularly in Harris' depiction of a future controlled by the church, but at the same time, the novels' emphasis on a resurgent nonhuman agentiality begs the obvious question: for whom or what is this dystopian? Given their insistence on the entanglement of human and nonhuman worlds, do these novels perhaps encode the possibility of an alternate to modernity and its myths, an alternate in which ecocentric thinking is both possible and necessary? That alternate does not lie in the primitive, tribal society that Jefferies described, nor in the reactionary, 
authoritarian society that Harris depicts, but Felix's and Fairfax's failed acts of resistance to the norms of their own kind nevertheless admit the possibility that where they have led, others may follow. Perhaps, therefore, these narratives are utopian by virtue of their refusal to close off the possibility of what is yet to come, utopian, that is, in the openended sense of the 'critical utopia', as the non-prescriptive basis for 'the imagination of transgressive and oppositional ecotopian alternatives' (Ibid: 397). As both novels imply, however, even tentative, critical forms of utopia cannot exist without the kind of self-reflexivity (and by extension knowledge and understanding) that is so conspicuously absent from these future worlds, each another risk society in the (re)making.

Difficult as it may be to classify these novels, it is nevertheless clear that they operate very differently to the modern, realist novel, whose limitations Ghosh identifies as part of the 'Great Derangement' (2016: 11); their departure from conventional realist norms is not incidental but central to their importance as part of the literary response to modernity, to its risks, to its uncertainty, and central to their bearing on cli-fi, as a (sub)genre that is itself seeking to find the representational means by which to engage with the unprecedented challenges of the Anthropocene.

\section{Conclusion}

According to Timothy Clark, 'innumerable so-called Cli Fi novels [resort] to cultural stereotypes', often dystopian, often 'with a focus on future environmental disasters such as devastating flooding [...] or on collapsed societies' (2015: 78-9). 'Such approaches', Clark insists, 'evade most of the present-day moral, political dilemmas by simply jumping ahead to some far more straightforward depiction of future disaster' (Ibid: 79), a point that Trexler also acknowledges (Trexler, 2015: 237). What is needed, Clark implies, is a dose of reality, and it is notable that, as Trexler argues, 'realist fiction about the Anthropocene' (Ibid: 233) is on the increase, as climate change necessarily ceases to be seen as 'a distant hypothetical future' that can 'be endlessly deferred' (Ibid: 223, 233), but as a part of lived existence (Ghosh, 2015: 72-3). 'The rise of realist fiction' (Trexler, 2015: 233) is, however, problematic in two ways.

Firstly, realist fiction is, Ghosh argues, a flawed medium, whose roots lie in the same frameworks of understanding that have created the conditions for climate change. As Trexler notes, 'there remain real limits to realist fiction' (2015: 233), not least its inability to transcend its own concentration on human as opposed to non-human agency. Secondly, and even as 'the Anthropocene real' (Ibid: 226) becomes a part of everyday life, the future is still entangled in 'climactic and political feedback loops' (Ibid: 223) that make it difficult to know what the future might bring, or whether it is yet possible to avert the worst outcome(s). Consequently, 
there may yet be a role for non-realist, experimental forms of fiction (whether we call this form of fiction 'cli-fi' or just another branch of sf). The question, nonetheless, is whether there is a place for novels like After London and The Second Sleep. With their predictions of an insurmountably bleak future, do they not encourage a fatalistic sense that nothing now can be done, an 'apocalypse fatigue that once again distances representation from the real' (Lawrence, 2020: 307-8)? To the contrary, both novels insist that the apocalypse - the 'event' - is not the end of the world: not of the non-human world, which thrives now that humankind has been disempowered, nor even the end of the human world, but simply of modern, technological civilization, a recent invention and legacy of the Enlightenment. The last word of both novels is their open endings, endings that suggest that the future is still there to be written beyond the worlds they depict. By refusing to foreclose future possibilities, and in so doing avoiding the traditional, formal utopia, 'closed, static, and prescriptive' (Garforth, 2005: 397), they open up a space within which the reader might yet envisage some as yet unimagined and as yet unwritten alternative to modernity.

At the same time, these novels introduce a note of caution. In both, fictive future worlds look back to technological civilizations that were undone by risks of their own making. The futures brought about by their collapse are themselves crippled by their ignorance, their condition of not-knowing, and the greatest of the gaps in their knowledge is the failure to understand what went wrong. Without that understanding, it might be argued, these future societies may in time simply take up the same modernizing path to the same catastrophic outcomes. As the climate change debate underlines, uncertainty is a lever that sceptics use to prevent a society from responding to the risks of its own creation; uncertainty can also be a reason to act, as the uncertainty principle suggests; but it is difficult to act when the risks that modernity generates take the form of Morton's elusive hyperobjects, unforeseen, nonlocal, and hyper relative to our knowledge (2013: 2).

The related point is that modern epistemologies may themselves be faulty: societies fail not because of what they do not know, but because of how they conceive of what they do. Arguably, this is the message of postequilibrium ecological thinking, quantum physics, and post-normal science (Garrard et al, 2019: 217-8), all of which point to the need for Western societies to reconceptualise their relationships to a dynamic agential materiality of which they themselves are a co-constitutive part. Instead, and even though it has provided the conceptual tools to transcend itself, modernity continues to insist on a nature-culture dualism - a 'Great Divide' - which is, as Bruno Latour has argued (1993: 12), a function of a stalled 'modern critical stance' (11) that is continually stymied by the 
dynamic interplay 'of nature and society' (Beck, 1995: 7). To be truly modern - that is, to mark a distinctive break with and transcend what Beck calls 'the continuation of the Enlightenment to technological ends' (Ibid: 6) - is to accept the entanglement of human with 'non-human' and 'morethan-human' worlds, and embrace a self-reflexive mode of knowing and being that manages (rather than banishing) uncertainty (Garrard et al., 2019: 217).

It also follows that the most relevant and compelling Anthropocene fictions are those that reflect the way in which 'Nature' (intrusive and unavoidable) forms part of the everyday. 'Nature' is also an integral and important part of both these novels, in which the subject is not simply modernity and its failings, or a newly rediscovered awareness 'of the precariousness of human existence' (Ghosh, 2016: 55), but a sense of 'apparently inanimate things comings suddenly alive' (Ibid: 63), and of '[s]omething planetary ... breaking through' (Clark, 2015: 9). Yet here, too, we can make one final distinction: the agentiality of the non-human world in Harris' novel is a felt presence, there to be recognised, but it is in Jefferies' disconcerting, late-Victorian novel that the non-human world erupts most vividly; in this radical and experimental narrative, a hybrid of chronicle and quest, the non-human emerges most fully as an agency with which human histories are inescapably caught up. Arguably, it is this recognition that unites Jefferies' proto-ecological novel with the 'future imaginaries' (Lawrence, 2020: 322) that a time of climate crisis demands.

Dr. Adrian Tait is an independent scholar and ecocritic with a particular interest in literary representations of environmental crisis. He has published related papers in a number of scholarly journals, including Green Letters: Studies in Ecocriticism (2018) and European Journal of English Studies (2018), and contributed to essay collections such as Nineteenth-Century Transatlantic Literary Ecologies (2017), Perspectives on Ecocriticism (2019), and Gendered Ecologies (2020). He is currently at work on a monograph provisionally entitled Environmental Justice, Agential Realism and the Victorian Literary Imagination. 


\section{References}

Beck, U., (1992). Risk Society: Towards a New Modernity, transl. M. Ritter. London: Sage (originally published in 1986).

Beck, U., (1995). Ecological Politics in an Age of Risk, transl. A. Weisz.

Cambridge: Polity Press (originally published in 1995).

Clark, C., (2019). The Second Sleep by Robert Harris review - a 'genre-bending thriller'. The Guardian, 7 September. Available at:

https://www.theguardian.com/books/2019/sep/07/the-second-sleep-robertharris-review [Accessed: 27 May 2020].

Clark, T., (2015). Ecocriticism on the Edge: The Anthropocene as a Threshold Concept. London: Bloomsbury Academic.

Frost, M., (2017). Introduction. In: Jefferies, R., After London; or Wild England. Edinburgh: Edinburgh University Press, pp. vii - xlvi.

Garforth, L., (2005). Green Utopias: Beyond Apocalypse, Progress, and Pastoral. Utopian Studies, 16(3), pp. $393-427$.

Garrard, G., A. Goodbody, G. B. Handley, and Posthumus, S., (2019). Climate Change Scepticism: A Transnational Ecocritical Analysis. London: Bloomsbury Academic.

Ghosh, A., (2016). The Great Derangement: Climate Change and the Unthinkable. Chicago: University of Chicago Press.

Harris, R., (2019). The Second Sleep. London: Hutchinson.

Hooker, J., (1996). Writers in a Landscape. Cardiff: University of Wales Press.

Jefferies, R., (2017). After London; or Wild England. Edinburgh: Edinburgh University Press (originally published by Cassell and Company in 1885).

Johns-Putra, A., (2016). Climate change in literature and literary studies: from cli-fi, climate change theater and ecopoetry to ecocriticism and climate change criticism. WIREs Clim Change, 7, pp. 266-282.

Latour, B., (1993). We Have Never Been Modern, transl. C. Porter. Cambridge, MA: Harvard University Press.

Lawrence, N., (2020). Post-Capitalist Futures: A Report on Imagination. In Kendal, Z., A. Smith, G. Champion, and Milner, A., Ethical Futures and Global Science Fiction, London: Palgrave Macmillan, pp. $303-327$.

MacDuffie, A., (2018). Charles Darwin and the Victorian Pre-History of Climate Denial. Victorian Studies, 60(4), pp. 543-564 .

Milner, A. and Burgmann, J. R., 2018. A Short Pre-History of Climate Fiction. Extrapolation, 59(1), pp. 1-23.

Morton, T., (2013). Hyperobjects: Philosophy and Ecology after the End of the World. Minneapolis: University of Minnesota Press. 
Thomas, E., (1909). Richard Jefferies: His Life and Work. London: Hutchinson \& Co.

Trexler, A., (2015). Anthropocene Fictions: The Novel in a Time of Climate Change. London: University of Virginia Press.

\section{To cite this article:}

Tait, A., 2020. Article Environmental crisis, cli-fi, and the fate of humankind in Richard Jefferies' After London and Robert Harris' The Second Sleep. Exchanges: The Interdisciplinary Research Journal, 8(2), 69-83. Available at: https://doi.org/10.31273/eiri.v8i2.554. 